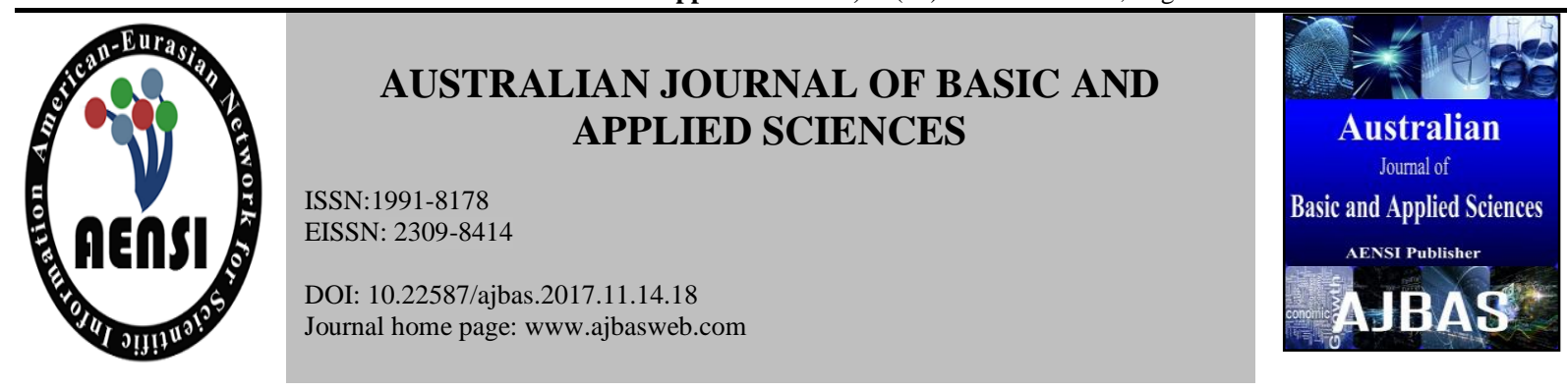

\title{
Awareness of Effect Diabetes Type 1 on Quality of Life in school child Through Educational
}

Dr. Mohammad Faiyadhah ${ }^{1}$, Dr. Thuraya Ahmad Rumbo $^{2}$, Dr. Fahad Almasaudi ${ }^{1}$, Abdallah Alehyani ${ }^{3}$, Mohammed Ahmed Omar Almahmudi ${ }^{4}$,Essam Eid Sady Alsubhi ${ }^{3}$

${ }^{1}$ General Doctor, KSA

${ }^{2}$ Family Medicine Specialist, KSA

${ }^{3}$ Nursing Technician, KSA

${ }^{4}$ Health Administration, KSA

Address For Correspondence:

Dr. Mohammad Faiyadhah: General Doctor, KSA

E-mail: dr.maf@live.com

\section{A RT I CLE INFO}

\section{Article history:}

Received 12 October 2017

Accepted 22 November 2017

Available online 6 December 2017

Keywords:

Awareness, Effect, Diabetes Type 1, Quality of Life, school child, Educational.

\begin{abstract}
A B S T RA C T
Background: Type 1 diabetes in children is a condition in which your child's body no longer produces an important hormone (insulin). Your child needs insulin to survive, so you'll have to replace the missing insulin. Type 1 diabetes in children used to be known as juvenile diabetes or insulin-dependent diabetes. The diagnosis of type 1 diabetes in children can be overwhelming at first, suddenly. Type 1 diabetes in children requires consistent care. Diabetes mellitus is a greatly predominant chronic disease. Type 1 diabetes mellitus often improves through the first stage of life and may influence the goodness of healthy adolescents. Type 1 diabetes may current at any age, but great generally does, therefore, among the age of 5 years and puberty. The diagnosis is proposed by beginning in childhood or early adult life or fast onset with early demand for insulin, the reported death rate from diabetes for children under 15 years of age was $1.3 / 100,000 /$ year in the U.S. Kingdom of Saudi Arabia supporting more than 33.3 million people, about 35,000 children, and adolescents suffer fromT1DM, which makes Saudi Arabia ranked the 8th in terms of numbers and 4th country in the world in terms of the incidence rate (33.5 per 100,000 people) of TIDM. Self-care supported that the daily routine of insulin, nutrition, and blood testing is preserved. Aim of this study is to help the child, parent and the staff knowledge of what to do and why it is, therefore, significant for the child or young person's safety and happiness to project in place to cover cases that may happen in school. Methodology: Cross-sectional design was adopted in the present study were collected in diabetes clinics in Descriptive study. The present study was conducted at primary and scenery school governmental \& private. The sample (200) practitioners from school governmental \& private they used questionnaire. Results our participants were noticed between age group 30 - 40 years, the majority of participants female's gender was $(77.50 \%)$, The awareness role of the Health Authority in the Kingdom for this disease is very weak, the majority of our participants were noticed average was $(55.00 \%)$ and weak knowledge $(32.50 \%)$ and high was $(12.50 \%)$ with a statistically significance P-value $(<0.001)$ and Chi-square( 54.250).Conclusion: The danger of delayed complexities of diabetes excess with accumulative exposure to high blood glucose levels and therapy that going back to circulating glucose to near-normal levels keeping versus these long-run complexities. Prospects for future treatment involved early protection or stem cell transplantation, renewal of surviving beta cells and gene therapy. Recommendations: Reinforcement of the knowledge was given through this research is fundamental to elevating sustained behaviour alteration in the society there is needed to increase in research on T1DM in Saudi Arabia.
\end{abstract}

\section{INTRODUCTION}

Members of the family are could be influenced by diabetes and its therapy may be caused decreased quality of life. There are in depth studies that judge the medical, social, and psychological impact of diabetes on

Open Access Journal

Published BY AENSI Publication

(C) 2017 AENSI Publisher All rights reserved

This work is licensed under the Creative Commons Attribution International License (CC BY).

http://creativecommons.org/licenses/by/4.0/

\section{Open Access}

To Cite This Article: Mohammad Faiyadhah, Thuraya Ahmad Rumbo, Fahad Almasaudi, Abdallah Alehyani, Mohammed Ahmed Omar Almahmudi, Essam Eid Sady Alsubhi Awareness of Effect Diabetes Type 1 on Quality of Life in school child Through Educational Aust. J. Basic \& Appl. Sci., 11(13): 144-154, 2017 
children until yet not several discuss the malady and its direct impact on members of the family, and even fewer investigate the money problems in relation to diabetes and its oral complications (Noueiri and Nassif 2018). There are two forms of type 1 diabetes:

- Idiopathic type 1. This refers to rare forms of the disease with no known cause.

- Immune-mediated diabetes. An autoimmune disorder in which the body's immune system destroys. (Imagawa et al., 2000).

The biological process changes that occur as school-age youngsters with type 1 diabetes grow into adolescence necessitate frequent appraisal of their therapeutic desires. Personal variations in caloric connected with growth and involvement in sports and adolescent temper swings are all agents that families could be contemplated in administer care and giving supports self-care by these youths. Wagner et al. (2005) Must by a reconciliation act among the quantity of nutrition devoured, the practice is accepted, and insulin injected to keep up secure glucose level, it will troublesome to youngsters, also their parents the administer and support from the school workers thus necessary (Copenhaver and Hoffman 2017).

Diabetes could be a dangerous, advanced complex health case demanding constant administration, support, and care. Its influences about eleven,000 school-aged children and young people in Australia and also it is one amongst the greatest averages within the world. If not therapy suitable, diabetes can pose instantaneous life-threatening health dangerous and could be the idea of with a similar state of being serious like bronchial asthma attacks and hypersensitivity reaction (Phelan et al., 2017).

The long goal of diabetes care is to keep up blood glucose among or near to physiological normality and to cut back the incidence of long-term complications of disease (Tahirovic and Toromanovic 2010). Registry knowledge on patients with type 1 diabetes mellitus who undergo pancreatic islet transplantation indicate that solely eight $\%$ are freed from the necessity insulin therapy at one year (Shapiro et al. 2000).

Exercise is additionally a crucial facet of polygenic disease management. it's real benefits for a toddler with diabetes disease. Patients should be encouraged to exercise frequently. American Diabetes Association. (2003)

The management of youngsters and kids with diabetes disease create extra challenges within the variety of emotional and psychological difficulties. Stress, in itself, might dysregulate polygenic disease through psycho-physiological processes or associated changes in self-management behaviors (Khandelwal et al., 2016).

Self-care is definitive to conduct oneself for individuals who are living with and conforming to, the diabetes disease, therefore, Youngsters and adolescents that may be a chronic condition, needs several changes, like adhering to treatment. Type 1 diabetes is an associate auto-immune situation could be the body devastates the cells which produce insulin. Insulin secretion that adjusts the glucose within the body and it was conjointly allows cells to utilize that glucose to produce power. Grey et al. (2009) showed that the necessity for employees to grasp that if a baby, they'll realize it tough to focus, If the level of glucose is elevated, they'll additionally feel thirsty and the necessity to go to the toilet. The work needed to perfect of these things typically just straight forward (Kaul et al. 2013)

Community health board features to make sure each kid be given the proper therapy to permit them to become a good boy as attainable. keeping a safe childhood and young hood and It right for every child are 2 elementary documents that could be at the center of understanding that a child or young people with diabetes in school (Streisand and Monaghan. 2014).

Type 1 diabetes mellitus (T1DM) is kind of prevailing within the world, with a proportion of one in each three hundred persons and steady rising frequency of incidence of concerning third-dimensional per annum. Diabetes Prevention Trial-Type 1 Diabetes Study (Group 2002).

Comparison therewith within the advanced towns, the quantity analysis involvements on the happening, in addition, socio-demographic sides of T1DM is not enough during this paper, therefore, we have a tendency to discuss completely various sides of T1DM in Saudi Arabia depending on the printed literature presently out there (Robert et al.(2018).

Through the last thirty years, the propagation of increasing the bodyweight has tripled between individuals ranged from 6 to 19 years old. This obesity may cause high blood pressure, high cholesterolemic, and high diabetics (Levin et al. 2003).

The care of a childhood individual with Type 1 diabetes in school is a group effort. This successfully demands each one included to act their part (Gubitosi-Klug et al. 2017).

As the incidence of type 1 diabetes in children and adolescents will increase, it becomes progressively important to differentiate recently diagnosed type 1 from type 1 diabetes. within the slender child, one one can confidence assume a designation of type 1 diabetes disorder. However, within the overweight adolescent, differentiating type 1 from type 2 diabetes may be difficult Silverstein (, Klingensmith 2005).

\section{Research Problem}

Kingdom of Saudi Arabia supporting more than 33.3 million people, about 35,000 children, and 
adolescents suffer fromT1DM, which makes Saudi Arabia ranked the 8th in terms of numbers and 4th country in the world in terms of the incidence rate ( 33.5 per 100,000 people) of TIDM. Self-care supported that the daily routine of insulin, nutrition, and blood testing is preserved.

\section{Aim of study}

Aim of study to help the child, parent and the staff knowledge of what to do and why it is, therefore, significant for the child or young person's safety and happiness to project in place to cover cases that may happen in school.

\section{Research objectives:}

1. Helping your child cope with type 1 diabetes

2. Define the parents of children with diabetes that their children enjoy the same social rights as other children.

3. Awareness of the Nutritional and physical activity risk factors on type 1 Diabetes Mellitus on children

\section{Research hypothesis}

Lack of awareness in parents about the T1DM in children

\section{METHODOLOGY}

\section{Research design:}

Cross-sectional design was adopted in the present study were collected in diabetes clinics in Descriptive study

\section{Setting:}

The present study was conducted at primary and scenery school governmental \& private.

\section{Study Sampling:}

The sample (200) practitioners from school governmental \& private they used questionnaire

\section{Statistical analyzed:}

Data was analyzed using SPSS version 20. The names of the participants were kept confidential

\section{Previous studies:}

Saudi Arabia is the biggest country in the Asia continent that had contained about four-fifths of the Arabian Peninsula supporting and consists of more than 33.3 million individual, of whom $26 \%$ are under the age of 14 years diabetics according to Diabetes Atlas (8th edition), could be 35,000 children and adolescents.

\section{Content Validity and reliability:}

Tool well be submitted to a panel of experts in the field to test the content validity. Modification was carried out according to the panel judgment on clarity of sentences and appropriateness of content.

\section{RESULTS}

Age

In our study, showed that the majority of participants $(57.5 \%)$ were within the age group 30 - 40 years, while the age group $<30$ year was represented $25 \%$ but the participants, where only $17.5 \%$ of participants were within the age group $>40$ years. The age Range was $25-48$ years and the age Mean \pm SD was 35.154+6.87.

\section{Gender}

The Female's gender was (77.50\%) while Male were $(22.50 \%)$ of participants.

\section{Level of education}

The majority of our participants were at Primary level were constitutes $38.00 \%$.

The most illustrative finding was that Secondary participants were constitutes $28.00 \%$ and Intermediate education were constituted (24.0\%).

\section{Occupation}

In our study, work participants constituted $66.50 \%$ of our study. While not work $33.50 \%$ of our study . Economic level 
In our study, Economic level Average participants constituted $55.00 \%$ of our study. While low level were $37.50 \%$ but high Economic level were $7.50 \%$.

Table (1) The distribution of Socio-demographic data in study group

\begin{tabular}{|c|c|c|}
\hline & $\mathbf{N}$ & $\%$ \\
\hline \multicolumn{3}{|l|}{ Age } \\
\hline$<30$ & 50 & 25 \\
\hline $30-40$ & 115 & 57.5 \\
\hline$>40$ & 35 & 17.5 \\
\hline Range & \multicolumn{2}{|c|}{$25-48$} \\
\hline Mean+SD & \multicolumn{2}{|c|}{$35.154+6.87$} \\
\hline \multicolumn{3}{|l|}{ Gender } \\
\hline Female & 155 & 77.50 \\
\hline Male & 45 & 22.50 \\
\hline \multicolumn{3}{|l|}{ Level of education } \\
\hline Primary & 76 & 38.00 \\
\hline Intermediate & 48 & 24.00 \\
\hline Secondary & 56 & 28.00 \\
\hline High education & 20 & 10.00 \\
\hline \multicolumn{3}{|l|}{ Occupation } \\
\hline Work & 133 & 66.50 \\
\hline Not work & 67 & 33.50 \\
\hline \multicolumn{3}{|l|}{ Economic level } \\
\hline Low & 75 & 37.50 \\
\hline Average & 110 & 55.00 \\
\hline High & 15 & 7.50 \\
\hline
\end{tabular}

The testing tool included 20 objective questions about general knowledge about diabetes the 20 questions had answers limited to Yes, No or I do not know: these questions were analysed using the Chi square analysis.

The most of question addressed the general knowledge about diabetes there was low percentage answer "yes "give correct answer. While high percentage said "no" and "Don't know" give incorrect answer the results of Chi square test, statistically significant high differences. But the question number $5,9,10$ there was high percentage answer in correct answer .

Table 3 Responses to questions 1- 4 of the testing tool

Risk Factors and complications for Type 1 Diabetes

Question own in table 3 asked there are involvements to identify two danger agents for diabetes, specified a list of four items. Table 3 had contained the results for this question. The options often regularly specified on the pre-exam were obesity $(60.00 \%)$ and eating too more sugar $(80 \%)$, after that family history $(50.0 \%)$, and linked with a diabetic individual chosen least frequently (20\%).

\section{Complications of Diabetes}

The second question on the exam asked there are involvements to identify two long run complications of diabetes specified a list of two items. Table 3 had contained the results for this question. Renal failure (40.00 $\%)$ and liver diseases $(30.0 \%)$ were selected often a lot then the blindness (70\%) and cancer (15\%).

\section{Treatment of Diabetes}

Question 3 asked therapy of diabetes. Specified a list of two items to specific three methods it was utilized to control diabetes. Table 3 had contained the results for this question. A first, $80 \%$ of involvements were selected nutrition and practices, $70 \%$ specified pills, and $90 \%$ specified insulin shots. $20 \%$ of respondents' wrong answer specified surgery as a method to therapy diabetes.

\section{Things that lower your risk of developing diabetes}

Question 4 addressed three objects that you can be done to decrease the danger of improving diabetes. Table 3 has contained the results for this question. At first $80 \%$ eat less sugar respondents , 85\% chosen practice regularly, $75 \%$ Lose weight if you are overweight, $30 \%$ percentage of respondents incorrectly don eat 
carbohydrates. $70 \%$ take balanced nutrition with eating from all the food groups and $20 \%$ Stay away from an individual that has diabetes.50\% percentage of respondents incorrectly answer

Table 2: The general knowledge about diabetes

\begin{tabular}{|c|c|c|c|c|c|c|c|c|c|}
\hline \multirow{2}{*}{\multicolumn{2}{|c|}{$\begin{array}{l}\text { The general knowledge about } \\
\text { diabetes }\end{array}$}} & \multicolumn{2}{|c|}{ Yes } & \multicolumn{2}{|c|}{ No } & \multicolumn{2}{|c|}{$\begin{array}{c}\text { I do not } \\
\text { know }\end{array}$} & \multicolumn{2}{|c|}{ Chi-square } \\
\hline & & $\mathbf{N}$ & $\%$ & $\mathbf{N}$ & $\%$ & $\mathbf{N}$ & $\%$ & $\mathbf{X}^{2}$ & P-value \\
\hline 1 & $\begin{array}{l}\text { The cause of diabetes in } \\
\text { children differences from that } \\
\text { of adults. }\end{array}$ & 105 & 52.50 & 45 & 22.50 & 50 & 25.00 & 33.250 & 0.00 \\
\hline 2 & $\begin{array}{l}\text { Childhood diabetes is caused } \\
\text { by a lack of insulin supply }\end{array}$ & 119 & 59.50 & 35 & 17.50 & 46 & 23.00 & 62.530 & 0.00 \\
\hline 3 & $\begin{array}{l}\text { There many differences in the } \\
\text { causes and treatment of } \\
\text { disease Among adults and } \\
\text { young people? }\end{array}$ & 120 & 60.00 & 32 & 16.00 & 48 & 24.00 & 65.920 & 0.00 \\
\hline 4 & $\begin{array}{l}\text { Increase of DM type } 1 \text { in } \\
\text { child people }\end{array}$ & 135 & 67.50 & 50 & 25.00 & 15 & 7.50 & 114.250 & 0.00 \\
\hline 5 & $\begin{array}{l}\text { Shortness of breath and an } \\
\text { increase in the speed of the } \\
\text { symptoms that appear on the } \\
\text { diabetic child }\end{array}$ & 77 & 38.50 & 110 & 55.00 & 13 & 6.50 & 72.970 & 0.00 \\
\hline 6 & $\begin{array}{l}\text { A diabetic child feels coma } \\
\text { and anxiety }\end{array}$ & 127 & 63.50 & 28 & 14.00 & 45 & 22.50 & 84.070 & 0.00 \\
\hline 7 & $\begin{array}{l}\text { Diabetes is becoming more } \\
\text { common because of weight } \\
\text { gain }\end{array}$ & 67 & 33.50 & 25 & 12.50 & 108 & 54.00 & 51.670 & 0.00 \\
\hline 8 & $\begin{array}{l}\text { you know the prevalence of } \\
\text { diabetes in Saudi Arabia }\end{array}$ & 140 & 70.00 & 30 & 15.00 & 30 & 15.00 & 121.000 & 0.00 \\
\hline 9 & $\begin{array}{l}\text { The child need to stay in the } \\
\text { hospital if he has diabetes }\end{array}$ & 51 & 25.50 & 80 & 40.0 & 69 & 34.50 & 6.430 & 0.04 \\
\hline 10 & $\begin{array}{l}\text { A diabetic feel thirsty and } \\
\text { hungry }\end{array}$ & 45 & 22.50 & 112 & 56.00 & 43 & 21.50 & 46.270 & 0.00 \\
\hline 11 & You know what insulin & 100 & 50.00 & 55 & 27.50 & 45 & 22.50 & 25.750 & 0.00 \\
\hline 12 & $\begin{array}{l}\text { Increased urination times, and } \\
\text { increased amount of diabetes } \\
\text { symptoms in children }\end{array}$ & 125 & 62.50 & 60 & 30.00 & 15 & 7.50 & 91.750 & 0.00 \\
\hline 13 & $\begin{array}{l}\text { You know the most common } \\
\text { symptoms seen on a diabetic } \\
\text { child }\end{array}$ & 122 & 61.00 & 64 & 32.00 & 14 & 7.00 & 87.640 & 0.00 \\
\hline 14 & $\begin{array}{l}\text { Severe thirst and drinking } \\
\text { water in large quantities are } \\
\text { symptoms of diabetic in } \\
\text { children }\end{array}$ & 120 & 60.00 & 70 & 35.00 & 10 & 5.00 & 91.000 & 0.00 \\
\hline 15 & $\begin{array}{l}\text { A diabetic child feels anorexia } \\
\text { and weight loss. }\end{array}$ & 118 & 59.00 & 48 & 24.00 & 34 & 17.00 & 60.760 & 0.00 \\
\hline 16 & $\begin{array}{l}\text { Can a diabetic child grow } \\
\text { naturally like other children }\end{array}$ & 121 & 60.50 & 58 & 29.00 & 21 & 10.50 & 76.690 & 0.00 \\
\hline 17 & $\begin{array}{l}\text { A diabetic child feels tired, } \\
\text { sluggish and inactive }\end{array}$ & 119 & 59.50 & 60 & 30.00 & 21 & 10.50 & 73.030 & 0.00 \\
\hline 18 & $\begin{array}{l}\text { A diabetic child feels vomiting } \\
\text { and abdominal pain }\end{array}$ & 90 & 45.00 & 66 & 33.00 & 44 & 22.00 & 15.880 & 0.00 \\
\hline 19 & $\begin{array}{l}\text { Obesity lead to diabetes in } \\
\text { children }\end{array}$ & 97 & 48.50 & 38 & 19.00 & 65 & 32.50 & 26.170 & 0.00 \\
\hline 20 & $\begin{array}{l}\text { Is there a difference between } \\
\text { diabetes in the urine and sugar } \\
\text { in the blood }\end{array}$ & 109 & 54.50 & 60 & 30.00 & 31 & 15.50 & 46.630 & 0.00 \\
\hline
\end{tabular}


Question addressed anyone in your family or relatives been diagnosed with diabetes. Table 3 has contained the results for this question. Fathers $80 \%$ follow by the mother $60 \%$ and Brothers $50 \%$. I do not know $10 \%$.

Table 3 Responses to questions 1- 4 of the testing tool

\begin{tabular}{|c|c|c|}
\hline & $\mathbf{N}$ & $\%$ \\
\hline \multicolumn{3}{|c|}{1 Circle two (2) risk factors that increase the risk of developing type 2 diabetes: } \\
\hline Overweight & 120 & 60.00 \\
\hline Eating too much sugar & 160 & 80.00 \\
\hline Parent or sibling has diabetes & 100 & 50.00 \\
\hline Contact with someone who has diabetes & 40 & 20.00 \\
\hline \multicolumn{3}{|l|}{2 What are two harmful long-term complications of diabetes? } \\
\hline Cancer & 30 & 15.00 \\
\hline Kidney failure & 80 & 40.00 \\
\hline Liver disease & 60 & 30.00 \\
\hline Blindness & 140 & 70.00 \\
\hline \multicolumn{3}{|l|}{3 How is diabetes treated? } \\
\hline Diet and exercise & 160 & 80.00 \\
\hline Pills & 140 & 70.00 \\
\hline Surgery & 40 & 20.00 \\
\hline Insulin shots & 180 & 90.00 \\
\hline \multicolumn{3}{|c|}{4 Identify three things that you can do to lower your risk of developing diabetes. } \\
\hline Eat less sugar & 160 & 80.00 \\
\hline Exercise regularly & 170 & 85.00 \\
\hline Lose weight if you are overweight & 150 & 75.00 \\
\hline Don. eat carbohydrates & 60 & 30.00 \\
\hline Eat a balanced diet with food from all the food groups & 140 & 70.00 \\
\hline Stay away from people that have diabetes & 40 & 20.00 \\
\hline \multicolumn{3}{|c|}{ Has anyone in your family or relatives been diagnosed with diabetes (type I or II) } \\
\hline the mother & 120 & 60.00 \\
\hline the father & 160 & 80.00 \\
\hline Brothers / sisters lose weight if you are overweight & 100 & 50.00 \\
\hline children & 90 & 45.00 \\
\hline No, I do not know & 20 & 10.00 \\
\hline
\end{tabular}

Table 4 : Test was a yes or no question

\begin{tabular}{|c|c|c|}
\hline \multicolumn{2}{|c|}{ N } & \multicolumn{1}{|c|}{} \\
\hline Have you heard of diabetes or do you know someone who has diabetes? & 130 & 65.00 \\
\hline Yes & 70 & 35.00 \\
\hline No & 150 & 75.00 \\
\hline Is there a cure for diabetes? & 50 & 25.00 \\
\hline Yes & \multicolumn{2}{|c|}{} \\
\hline No & 140 & 70.00 \\
\hline Type 1 diabetes used to be seen only in older adults but now children are getting it as well & 30.00 \\
\hline Yes & 60 \\
\hline No & 160 & 80.00 \\
\hline The increase in diabetes in the Saudi Arabia is largely due to increased body weight & 20.00 \\
\hline Yes & 40 \\
\hline No & 90 & 45.00 \\
\hline Over 6 million Saudi children have diabetes & 110 & 55.00 \\
\hline Yes
\end{tabular}


In the additional this test was a yes or no question there was a significant increase in respondents answering correctly. But question Over 6 million Saudi children have diabetes $45 \%$ answering YES and NO $55 \%$.

Table 5 : Awareness role of the Health Authority in the Kingdom for this disease

\begin{tabular}{|c|c|c|}
\hline Awareness role of the Health Authority in the Kingdom for this disease \\
\hline Excellent & $\mathrm{N}$ & $\%$ \\
\hline Very good & 8 & 4.00 \\
\hline Not at the required level & 10 & 5.00 \\
\hline Low & 120 & 60.00 \\
\hline
\end{tabular}

The Awareness role of the Health Authority in the Kingdom for this disease Excellent role 4\% and very good $5 \%$ and Not at the required level $60 \%$ Low $31.5 \%$.

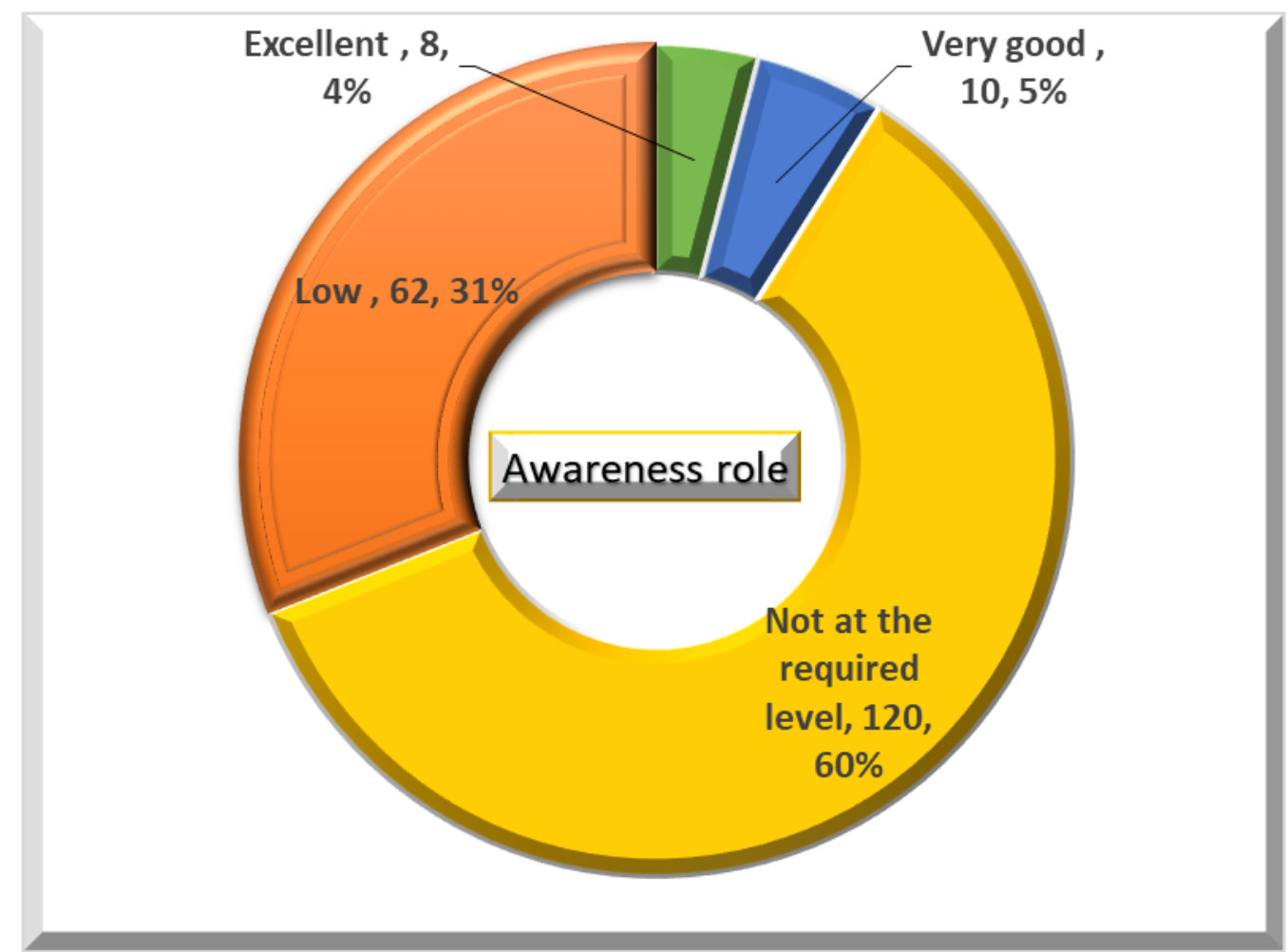

Figure 1: Awareness role of the Health Authority in the Kingdom for this disease

Table 6 : represents the knowledge

\begin{tabular}{|c|c|c|c|}
\hline \multicolumn{4}{|c|}{ Knowledge } \\
\hline & & $\mathrm{N}$ & $\%$ \\
\hline \multicolumn{2}{|c|}{ Weak } & 65 & 32.50 \\
\hline \multicolumn{2}{|c|}{ Average } & 110 & 55.00 \\
\hline \multicolumn{2}{|c|}{ High } & 25 & 12.50 \\
\hline \multicolumn{2}{|c|}{ Range } & \multicolumn{2}{|c|}{$5-24$} \\
\hline \multicolumn{2}{|c|}{ Mean \pm SD } & \multicolumn{2}{|c|}{$17.44 \pm 4.494$} \\
\hline \multirow{2}{*}{ Chi-square } & $\mathbf{X}^{2}$ & \multicolumn{2}{|c|}{54.250} \\
\hline & P-value & \multicolumn{2}{|c|}{$<0.001 *$} \\
\hline
\end{tabular}

It was noticed that the study the majority of our participants were noticed average was $(55.00 \%)$ and weak knowledge $(32.50 \%)$ and high was $(12.50 \%)$ with a statistically significance P-value $(<0.001)$ and Chisquare( 54.250) and Mean \pm SD (17.44 \pm 4.494$)$ but Range (5-24) . 


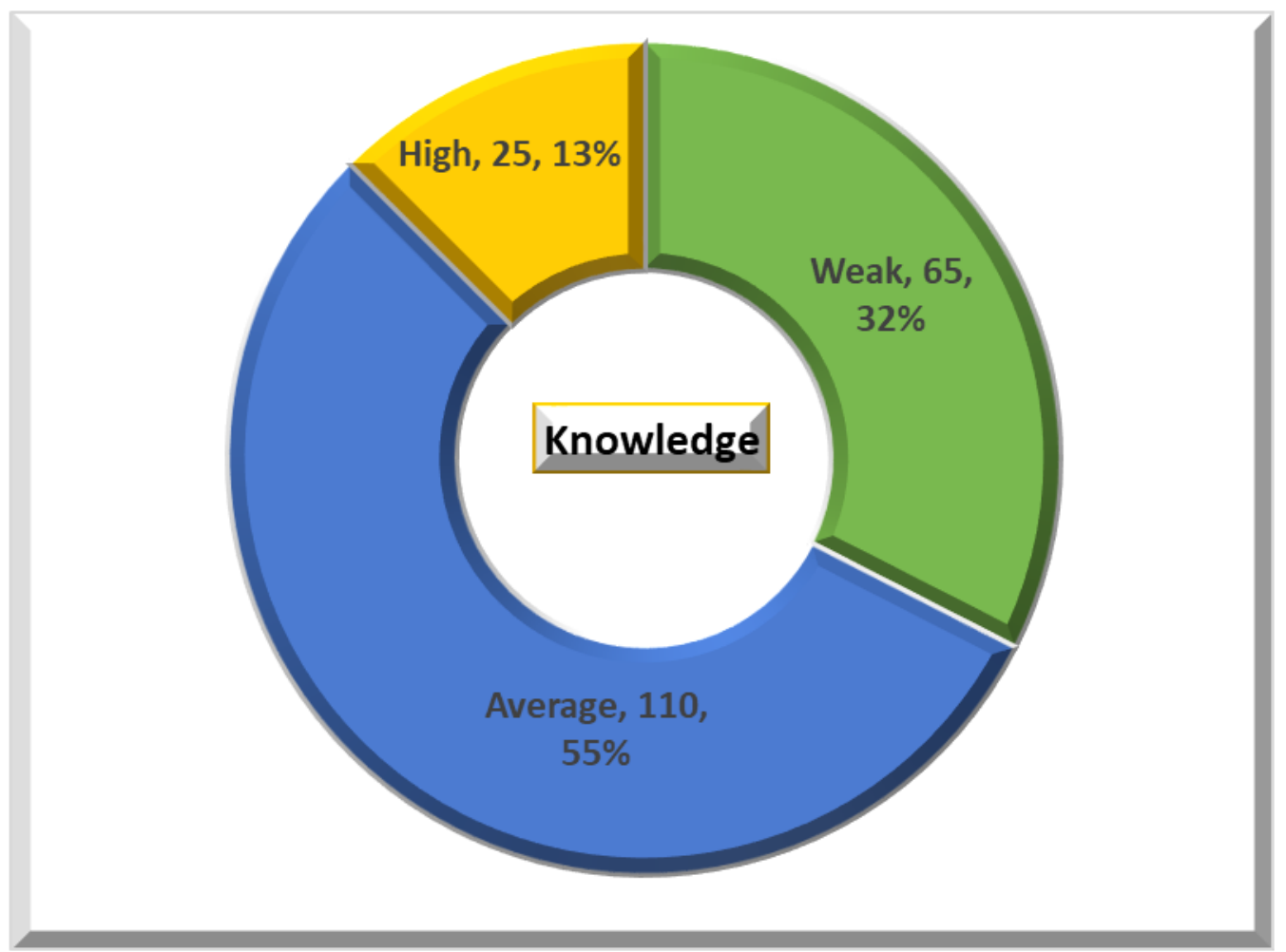

Figure 2: Bar graph represents the knowledge

It was noticed that the study the majority of our participants were noticed average was (55.00\%) and weak knowledge $(32.50 \%)$ and high was $(12.50 \%)$ The Figure 2 shows the detailed data.

Table 7: Demographic data \& Total knowledge

\begin{tabular}{|c|c|c|c|c|c|}
\hline \multirow[t]{3}{*}{ 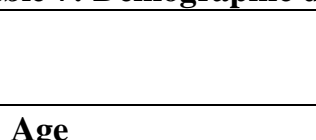 } & \multirow{2}{*}{$\mathbf{N}$} & \multirow{2}{*}{$\begin{array}{c}\text { Knowledge } \\
\text { Mean } \pm \text { SD } \\
\end{array}$} & \multirow{2}{*}{$\mathbf{F}$ or $\mathbf{T}$} & \multicolumn{2}{|c|}{ ANOVA or T-test } \\
\hline & & & & test value & P-value \\
\hline & \multicolumn{5}{|c|}{ Age } \\
\hline$<30$ & 50 & $11.64 \pm 2.211$ & \multirow{3}{*}{$\mathrm{F}$} & \multirow{3}{*}{195.076} & \multirow{3}{*}{$<0.001^{*}$} \\
\hline $30-40$ & 115 & $18.452 \pm 2.992$ & & & \\
\hline$>40$ & 35 & $22.429 \pm 1.614$ & & & \\
\hline \multicolumn{6}{|l|}{ Gender } \\
\hline Female & 155 & $19.045 \pm 3.613$ & \multirow{2}{*}{$\mathrm{T}$} & \multirow{2}{*}{12.444} & \multirow{2}{*}{$<0.001 *$} \\
\hline Male & 45 & $11.933 \pm 2.359$ & & & \\
\hline \multicolumn{6}{|l|}{ Level of education } \\
\hline Primary & 76 & $12.947 \pm 2.842$ & \multirow{4}{*}{$\mathrm{F}$} & \multirow{4}{*}{249.739} & \multirow{4}{*}{$<0.001^{*}$} \\
\hline Intermediate & 48 & $17.292 \pm 1.611$ & & & \\
\hline Secondary & 56 & $21.589 \pm 1.359$ & & & \\
\hline High education & 20 & $23.30 \pm 0.470$ & & & \\
\hline \multicolumn{6}{|l|}{ Occupation } \\
\hline Work & 133 & $18.180 \pm 3.433$ & \multirow{2}{*}{$\mathrm{T}$} & \multirow{2}{*}{3.343} & \multirow{2}{*}{$<0.001 *$} \\
\hline Not work & 67 & $15.985 \pm 5.837$ & & & \\
\hline \multicolumn{6}{|l|}{ Economic level } \\
\hline Low & 75 & $12.573 \pm 2.303$ & \multirow{3}{*}{$\mathrm{F}$} & \multirow{3}{*}{309.383} & \multirow{3}{*}{$<0.001 *$} \\
\hline Average & 110 & $19.90 \pm 2.299$ & & & \\
\hline High & 15 & $23.800 \pm 0.414$ & & & \\
\hline
\end{tabular}

Age:

In our study the majority of our participants were noticed between age 30-40 y with Mean \pm SD $(18.452 \pm 2.992)$ and a statistically significance $(\mathrm{F}=195.076 \mathrm{p}<0.001)$ 


\section{Gender:}

In our study the majority of our participants were noticed in female more than male with Mean \pm SD $(19.045 \pm 3.613)$ with a statistically significance $(T=12.444, \mathrm{p}<0.001)$.

\section{Level of education:}

In our study the majority of our participants were noticed primary education standard deviation was $(12.947 \pm 2.842)$ with a statistically significance $(\mathrm{F}=249.739, \mathrm{p}<0.001)$ the Secondary education and Intermediate less than primary with a statistically significance.

\section{Occupation:}

In our study the majority of our participants were noticed Occupation with standard deviation was $(18.180 \pm 3.433)$ with a statistically significance $(\mathrm{T}=3.343, \mathrm{p}<0.001)$.

\section{Economic level:}

In our study the majority of our participants were noticed Economic level Average with standard deviation was $(19.90 \pm 2.299)$ with a statistically significance $(F=309.383, p<0.001)$

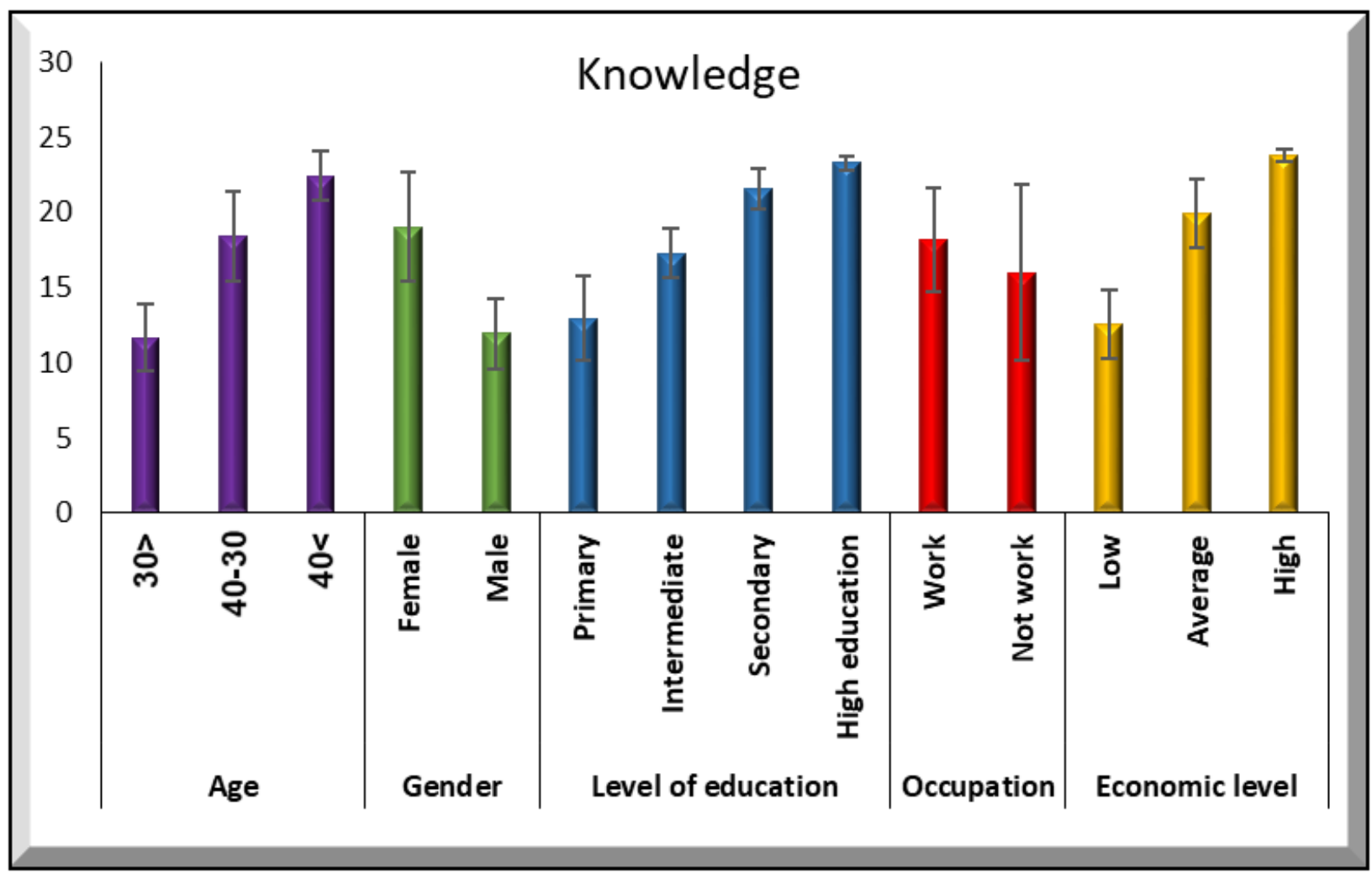

Figure 3: Bar graph represents Demographic data \& knowledge

\section{DISCUSSION}

Overall, the results from the analysis indicated and decrease information in our participants Female's gender in our study was $(77.50 \%)$ while Male were $(22.50 \%)$. Involvement in educational programs concentrated on general knowledge about diabetes, protection, and risk factor. Moreover, for some questions the correct answer great lowering, there was consistently a net gain generally. Repetition of the examiner was perhaps useful for some participants. In general, our studies the majority of our participants were noticed between age $30-40$ years more receptive. In our study the majority of our participants were noticed between age 30 - 40 years with a statistically significance $(\mathrm{F}=195.076 \mathrm{p}<0.001)$ In our study the majority of our participants were noticed in female more than male with Mean \pm SD $(19.045 \pm 3.613)$ with a statistically significance $(T=12.444, p<0.001)$ .In our study the majority of our participants were noticed primary education standard deviation was $(12.947 \pm 2.842)$ with a statistically $(\mathrm{F}=249.739, \mathrm{p}<0.001)$.In our study the majority of our participants were noticed Economic level Average with standard deviation was $(19.90 \pm 2.299)$ with a statistically significance $(\mathrm{F}=309.383, \mathrm{p}<0.001)$ In our study the majority of our participants were noticed Occupation with standard 
deviation was $(18.180 \pm 3.433)$ with a statistically significance $(T=3.343, \mathrm{p}<0.001)$.the table 7 shows the detailed data.

\section{CONCLUSION}

There is a dearth of meticulously conducted research on T1DM in Saudi Arabia. It is fortunate that there is goodness measures previously able to be used that have yet to be integrated into national-level. Considering the increasing prevalence of T1DM in Saudi Arabia, For example, all 15 specified general adolescent QOL measures situated for this include enough measures of emotional but in infants and young children Considering the increasing prevalence of T1DM in Saudi Arabia, especially, the research interventions need to be significantly improved well-being, Moreover, it is critical to develop appropriate management programs for controlling T1DM and allocating health resources appropriately for this condition. Research efforts should focus on achieving early diagnosis, preventing, and developing better treatment options to improve the quality of life and prognosis of the affected individuals (Dickinson and Parkinson 2007). Elements which could be combined into national-level scanning to promote the field of measurement systems, like the CWI. As well as, parents reported higher child QoL than did their children. but in regard to the self-report of 9-10 years old children, only the KINDL total QoL scale or the ILC are recommended (Jozefiak et al. 2008).

\section{RECOMMENDATIONS}

Strengthening of the knowledge given throughout this research is crucial to elevating sustained activity amendment within the society. giving programs aimed at identified youngsters and young adults have the possibility to be particularly helpful if healthy practices tested to cut back the chance of malady are founded soon in life. Combine such programs during school has the possibility to affect an oversized range of individuals, a group action is needed. Environmental amendment to support healthy practice, particularly at school, is definitive to affecting attitude amendment. Enough change for physical activity and healthy nutrition selections at schools important (Arnaud et al. 2008).

Parental participation within the teaching method is the second crucial step in supporting behavior amendment to lowering danger agents for chronic disease as a result of folks function extremely important role models. Community-wide involvement to the knowledge of danger agents for growing information of danger agents for chronic disease can be performed in a diversity of settings but would better be performed with some score of harmony therefore that programs carried at various locations and to varying age groups would support the same public messages to elevate health (Mustapha et al. 2014).

\section{REFERENCES}

1. American Diabetes Association. (2003). Physical activity/exercise and diabetes mellitus. Diabetes care, 26(suppl 1), s73-s77.

2. Arnaud, C., White-Koning, M., Michelsen, S. I., Parkes, J., Parkinson, K., Thyen, U. \& McManus, V. (2008). Parent-reported quality of life of children with cerebral palsy in Europe. Pediatrics, 121(1), 54-64.

3. Copenhaver, M., \& Hoffman, R. P. (2017). Type 1 diabetes: where are we in 2017? Translational pediatrics, 6(4), 359.

4. Diabetes Prevention Trial-Type 1 Diabetes Study Group. (2002). Effects of insulin in relatives of patients with type 1 diabetes mellitus. New England Journal of Medicine, 346(22), 1685-1691

5. Dickinson, H. O., Parkinson, K. N., Ravens-Sieberer, U., Schirripa, G., Thyen, U., Arnaud, C. \& Parkes, J. (2007). Self-reported quality of life of $8-12$-year-old children with cerebral palsy: a cross-sectional European study. The Lancet, 369(9580), 2171-2178.

6. Gubitosi-Klug, R. A., Braffett, B. H., White, N. H., Sherwin, R. S., Lachin, J. M., Tamborlane, W. V., ... \& Epidemiology of Diabetes Interventions and Complications (EDIC) Research Group. (2017). The risk of severe hypoglycemia in type 1 diabetes over 30 years of follow-up in the DCCT/EDIC Study. Diabetes Care, dc162723.

7. Grey, M., Whittemore, R., Jaser, S., Ambrosino, J., Lindemann, E., Liberti, L., \& Dziura, J. (2009). Effects of coping skills training in school-age children with type 1 diabetes. Research in nursing \& health, 32(4), 405-418.

8. Imagawa, A., Hanafusa, T., Miyagawa, J. I., \& Matsuzawa, Y. (2000). A novel subtype of type 1 diabetes mellitus characterized by a rapid onset and an absence of diabetes-related antibodies. New England journal of medicine, 342(5), 301-307.

9. Jozefiak, T., Larsson, B., Wichstrøm, L., Mattejat, F., \& Ravens-Sieberer, U. (2008). Quality of Life as reported by school children and their parents: a cross-sectional survey. Health and quality of life outcomes, $6(1), 34$. 
10. Kaul, K., Tarr, J. M., Ahmad, S. I., Kohner, E. M., \& Chibber, R. (2013). Introduction to diabetes mellitus. In Diabetes (pp. 1-11). Springer, New York, NY

11. Khandelwal, S., Sengar, G. S., Sharma, M., Choudhary, S., \& Nagaraj, N. (2016). Psychosocial illness in children with Type 1 Diabetes Mellitus: Prevalence, pattern and risk factors. Journal of clinical and diagnostic research: JCDR, 10(9), SC05.

12. Levin, S., Lowry, R., Brown, D. R., \& Dietz, W. H. (2003). Physical activity and body mass index among US adolescents: youth risk behavior survey, 1999. Archives of pediatrics \& adolescent medicine, 157(8), 816-820.

13. Mustapha, W., Hossain, Z. S., \& O’Loughlin, K. (2014). Management and impact of diabetes on quality of life among the Lebanese community of Sydney: A quantitative study. J Diabetes Metab, 5(329), 2.

14. Noueiri, B., \& Nassif, N. (2018). Impact of Diabetes Mellitus Type 1 on Lebanese Families' Quality of Life. International journal of clinical pediatric dentistry, 11(2), 61 .

15. Phelan, H., Clapin, H., Bruns, L., Cameron, F. J., Cotterill, A. M., Couper, J. J., ... \& Sinnott, R. O. (2017). The Australasian Diabetes Data Network: first national audit of children and adolescents with type 1 diabetes. Medical Journal of Australia, 206(3), 121-125.

16. Robert, A. A., Al-Dawish, A., Mujammami, M., \& Dawish, M. A. A. (2018). Type 1 Diabetes Mellitus in Saudi Arabia: A Soaring Epidemic. International journal of pediatrics, 2018.

17. Streisand, R., \& Monaghan, M. (2014). Young children with type 1 diabetes: challenges, research, and future directions. Current diabetes reports, 14(9), 520.

18. Shapiro, A. J., Lakey, J. R., Ryan, E. A., Korbutt, G. S., Toth, E., Warnock, G. L., ... \& Rajotte, R. V. (2000). Islet transplantation in seven patients with type 1 diabetes mellitus using a glucocorticoid-free immunosuppressive regimen. New England Journal of Medicine, 343(4), 230-238.

19. Silverstein, J., Klingensmith, G., Copeland, K., Plotnick, L., Kaufman, F., Laffel, L., \& Clark, N. (2005). Care of children and adolescents with type 1 diabetes: a statement of the American Diabetes Association. Diabetes care, 28(1), 186-212.

20. Tahirovic, H., \& Toromanovic, A. (2010). Glycemic control in diabetic children: role of mother's knowledge and socioeconomic status. European journal of pediatrics, 169(8), 961-964.

21. Wagner, V. M., Müller-Godeffroy, E., Von Sengbusch, S., Häger, S., \& Thyen, U. (2005). Age, metabolic control and type of insulin regime influences health-related quality of life in children and adolescents with type 1 diabetes mellitus. European journal of pediatrics, 164(8), 491-496.

22. Whittemore, Robin, Andrea Dann Urban, William V. Tamboriane, and Margaret Grey. "Quality of life in school-aged children with type 1 diabetes on intensive treatment and their parents." The Diabetes Educator 29, no. 5 (2003): 847-854. 